\title{
Etil Format sebagai Perlakuan Alternatif terhadap Colletotrichum gloeosporioides pada Stroberi
}

\author{
Ethyl Formate as Alternative Treatment against \\ Colletotrichum gloeosporioides on Strawberry
}

\author{
Ade Syahputra*, Nurul Dwi Handayani, Indriani Kusumawati Daud Malvini \\ Balai Uji Terap Teknik dan Metode Karantina Pertanian, Bekasi 17520
}

\begin{abstract}
ABSTRAK
Etil format (EtF) merupakan salah satu alternatif fumigan pengganti metil bromida. Penelitian ini bertujuan mendapatkan metode dan waktu perlakuan etil format yang efektif terhadap Colletotrichum gloeosporioides pada stroberi. Pengujian secara in vitro dilakukan pada medium potato dextrose agar yang sudah diinokulasi dengan isolat cendawan $C$. gloeosporioides. Cendawan difumigasi EtF di dalam kantong plasik berukuran $5 \mathrm{~L}$. Pada pengujian secara in vivo isolat cendawan berdiameter $0.3 \mathrm{~mm}$ diinokulasi pada buah stroberi yang sudah steril sebanyak 1 titik pada bagian yang dilukai. Buah yang sudah diinokulasi difumigasi EtF dengan perlakuan dosis $\left(0,140,190,240\right.$, dan $\left.290 \mathrm{~g} \mathrm{~m}^{-3}\right)$ dan waktu pemaparan (1, 2, 3, 4 jam, dan kontrol). Tiap pengujian diulang empat kali. Hasil pengujian menunjukkan adanya pengurangan pertumbuhan cendawan secara in vitro. Hasil in vivo menunjukkan EtF tidak mempengaruhi pertumbuhan cendawan dan pada dosis $190 \mathrm{~g} \mathrm{~m}^{-3}$ dapat mempengaruhi kerusakan kaliks, tetapi tidak mempengaruhi kualitas buah stroberi. Cendawan lain yang muncul pada buah stroberi setelah perlakuan adalah Colletotrichum sp. dan Botrytis sp.
\end{abstract}

Kata kunci: Colletotrichum gloeosporioides, etil format, stroberi

\begin{abstract}
Ethyl formate (EtF) is alternative fumigant to substitute methyl bromide. The objective of the current study was to obtain an effective dose and exposure time of Etf treatment against Colletotrichum gloeosporioides in strawberry. In vitro test was conducted on colonies of C. gloeosporioides grew on PDA in petri dishes. The fungus was fumigated with Etf at various dose $(0,140,190,240$, and $\left.290 \mathrm{~g} \mathrm{~m}^{-3}\right)$ and at various exposure time (1, 2, 3, and 4 hours), in $5 \mathrm{~L}$ plastic bags. On in vivo test, agar plugs of $C$. gloeosporioides (diameter $0,3 \mathrm{~mm}$ ) were inoculated on to wounded strawberries, and the inoculated strawberries were then fumigated with Etf at similar dose and exposure time treatments. Each test was conducted in four replicates. Fumigation with Etf at $190 \mathrm{~g} \mathrm{~m}^{-3}$ significantly reduced the growth of $C$. gloeosporioides on agar, but did not reduce the colonization of the pathogen on strawberries. Ethyl formate did not affect visual quality of strawberries, but damaged the calyx at $190 \mathrm{~g} \mathrm{~m}^{-3}$. Other fungi, namely Colletotrichum sp. and Botrytis sp., were found on fumigated and nonfumigated strawberries.
\end{abstract}

Key words: Colletotrichum gloeosporioides, ethyl formate, strawberries

*Alamat penulis korespondensi: Balai Uji Terap Teknik dan Metode Karantina Pertanian, Jalan Raya Kampung UtanSetu, Mekar Wangi, Cikarang Barat, Bekasi 17520

Tel: 021-82618923, Faks: 021-82618923, Surel: ade@buttmkp.org, ade.bkp@gmail.com 


\section{PENDAHULUAN}

Indonesia merupakan salah satu negara penghasil beragam buah-buahan. Stroberi merupakan salah satu jenis buah-buahan Indonesia yang memiliki volume ekspor impor cukup tinggi. Dibandingkan dengan tahun sebelumnya, pada tahun 2011 terjadi penurunan jumlah nilai impor dan ekspor buah stroberi segar berturut-turut sebesar 1072230 US\$, dan 376321 US\$. Beberapa negara tujuan ekspor buah stroberi ialah Jepang, Uni Emirat Arab, Brunei Darussalam, Singapura, Malaysia, dan Thailand (Ditlin Hortikultura 2011).

Salah satu kendala dalam ekspor buah stroberi ialah gangguan penyakit sejak di pertanaman hingga penyimpanan. Beberapa patogen penyebab penyakit pascapanen pada stroberi ialah Colletotrichum spp., Botrytis cinerea, dan Rhizopus stolonifer yang mengakibatkan busuk buah dan menurunkan kualitas buah stroberi. Potensi kerusakan buah stroberi yang terinfeksi C. gloeosporioides mencapai $90 \%$ dalam waktu seminggu atau kurang dari seminggu (Ellis dan Erincik 2008).

Badan Karantina Pertanian (Barantan) sebagai koordinator dalam national plant protection organizations (NPPOs) berfungsi sebagai pengambil kebijakan dalam melakukan harmonisasi, pengakuan dan pengembangan keahlian dan kerja sama teknis dalam pelaksanaan perdagangan bebas, khususnya komoditas pertanian. Sejak 2012 Barantan resmi menggunakan etil format (EtF) sebagai salah satu bahan aktif pestisida untuk perlakuan karantina.

Etil format (EtF) merupakan salah satu alternatif fumigan untuk menggantikan metil bromida yang dapat mengakibatkan penipisan lapisan ozon (Fields dan White 2002). EtF sebagai senyawa organik juga digunakan sebagai alternatif pengganti fungisida sintetik terhadap produk pertanian (Gorris dan Smid 1995). Senyawa ini mudah menguap dan terdapat secara alami dalam berbagai produk, termasuk daging sapi, keju, beras, buah anggur, dan minuman anggur. Senyawa ini umumnya diakui sebagai suatu senyawa aman (generally recognize as safe/GRAS) (EMA 2009).

Perlakuan senyawa EtF belum banyak dilaporkan pada cendawan, meskipun perlakuan untuk serangga sudah ada laporannya. Damcevski et al. (2010) melaporkan bahwa perlakuan EtF dengan dosis $193 \mathrm{~g} \mathrm{~m}^{-3}$ selama 1 jam efektif menekan hingga 92\% seluruh stadium serangga gudang Rhizoperta dominica, Sitophilus oryzae, dan Tribolium castaneum. Oleh karena itu, tujuan penelitian ini ialah menentukan dosis dan waktu yang efektif untuk perlakuan EtF terhadap C. gloeosporioides pada stroberi yang diharapkan juga tidak merusak kualitas buah.

\section{BAHAN DAN METODE}

\section{Bahan Fumigasi EtF dan Perbanyakan Biakan Murni C. gloeosporioides}

Pengujian ini menggunakan dosis produk EtF yang sudah dicampur dengan komposisi $16.7 \%$ EtF dan $83.3 \% \mathrm{CO}_{2}$. Fumigasi EtF dilakukan dengan evaporator yang sudah dirakit/dimodifikasi untuk skala laboratorium sehingga EtF dan $\mathrm{CO}_{2}$ yang dikeluarkan dari alat tersebut sudah dalam bentuk gas.

Isolat $C$. gloeosporioides yang digunakan merupakan isolat koleksi BUTTMKP. Biakan murni ditumbuhkan pada medium PDA 2\% di dalam cawan selama tujuh hari di bawah sinar NUV dengan pengaturan 12 jam gelap dan 12 jam terang.

\section{Perlakuan EtF secara in Vitro terhadap Biakan Murni C. gloeosporioides}

Biakan murni $C$. gloeosporioides yang berumur satu bulan diambil dengan bor gabus berdiameter $0.3 \mathrm{~mm}$ dan diletakkan dalam cawan yang berisi medium PDA. Masingmasing cawan tersebut dibuka tutupnya dan dimasukkan dalam kantong plastik transparan volume $5 \mathrm{~L}$ sebagai satu unit percobaan. Fumigan diinjeksikan pada plastik tersebut dengan dosis $0,140,190,240$, dan $290 \mathrm{~g} \mathrm{~m}^{-3}$ dalam waktu paparan 1, 2, 3, dan 4 jam. Masing-masing perlakuan diulang sebanyak empat kali. Suhu di dalam plastik berkisar antara 23 dan $28^{\circ} \mathrm{C}$. Setelah mencapai 
waktu paparan dilakukan aerasi di ruang asap (fume hood). Pengamatan dilakukan setiap hari hingga tujuh hari dengan mengukur diameter koloni cendawan.

Perlakuan EtF secara in Vivo terhadap C. gloeosporioides pada Buah Stroberi

Buah stroberi disterilkan bagian permukaannya dengan alkohol $70 \%$ dan dikeringanginkan sekitar lima menit. Koloni cendawan C. gloeosporioides diambil dengan menggunakan bor gabus berdiameter $0.3 \mathrm{~mm}$, potongan tersebut beserta agar-agarnya ditempelkan pada permukaan buah yang sudah dilukai dengan jarum inokulasi steril dengan kedalaman $0.5 \mathrm{~mm}$. Buah yang sudah diinokulasi cendawan dimasukkan ke dalam kantong plastik $5 \mathrm{~L}$ yang berisi cawan agar yang tidak ada penutup, tiap kantong plastik berisi lima buah stroberi. Gas EtF dimasukkan dengan dosis produk 0, 140, 190, 240 dan $290 \mathrm{~g} \mathrm{~m}^{-3}$ dan waktu paparan 1, 2, 3, dan 4 jam. Masingmasing perlakuan diulang sebanyak 4 kali. Sebagai pembanding dipersiapkan perlakuan kontrol tanpa fumigasi EtF. Buah stroberi yang diberi perlakuan ini kemudian disimpan di lemari pendingin pada suhu sekitar $13.4^{\circ} \mathrm{C}$. Pengamatan dilakukan tujuh hari setelah perlakuan (HSP) dengan mengamati perkembangan cendawan di bawah mikroskop stereo.

\section{Perkembangan $C$. gloeosporioides}

Pada pengujian in vitro, pengamatan dilakukan dengan mengukur diameter koloni C. gloeosporioides pada medium agar-agar. Pada pengujian in vivo, cendawan diamati di bawah mikroskop stereo dengan melihat adanya tanda penyakit C. gloeosporioides yang muncul pada buah stroberi 5-7 HSP. Pengamatan terhadap tumbuhnya cendawan lain diamati di bawah mikroskop cahaya.

\section{Pengamatan Kualitas Buah}

Pengamatan terhadap kualitas buah stroberi setelah perlakuan EtF dilakukan dengan uji organoleptik. Peubah yang diuji pada buah stroberi ialah kelopak, warna buah, dan tanda pertumbuhan cendawan lain. Penilaian kerusakan terhadap kelopak stroberi dihitung berdasarkan pengamatan visual metode Simpson et al. (2007) dengan skor sebagai berikut.

1, tidak ada kerusakan;

2 , sedikit ( $<20 \%$ kerusakan);

3 , moderat (20-60\% kerusakan);

4 , berat ( $>60 \%$ kerusakan).

Pengamatan buah stroberi dilakukan secara visual dengan skor sebagai berikut (Balitbang Pertanian 2012).

1, merah segar;

2, merah tua sedikit keriput;

3 , merah tua keriput;

4, merah kecokelatan keriput.

\section{Analisis}

Rancangan percobaan yang digunakan untuk perhitungan pada uji in vitro dan in vivo adalah rancangan acak lengkap faktorial. Perbedaan pengaruh perlakuan dianalisis dengan analisis ragam dan pemeriksaan terhadap perbedaan antarperlakuan diuji dengan uji Tukey pada taraf nyata 5\%. Perhitungan Anova dan uji Tukey tersebut dilakukan menggunakan Program SPSS 16.

\section{HASIL}

\section{Perlakuan EtF secara in Vitro terhadap Biakan Murni $C$. gloeosporioides}

Uji EtF terhadap C. gloeosporioides secara in vitro menunjukkan bahwa dosis minimal $190 \mathrm{~g} \mathrm{~m}^{-3}$ dapat mengurangi pertumbuhan cendawan dibandingkan dengan kontrol (Tabel 1). Pengujian pada medium PDA terlihat pertumbuhan koloni $C$. gloeosporioides di tiap dosis berkurang dibandingkan dengan kontrol.

Hasil analisis menunjukkan bahwa dosis berpengaruh secara nyata terhadap pertumbuhan diameter $C$. gloeosporioides $\left(\mathrm{F}_{4,80}=17.261 ; \quad \mathrm{P}=0.000\right)$. Namun, hasil analisis menunjukkan bahwa waktu tidak berpengaruh secara nyata terhadap diameter C. gloeosporioides $\left(\mathrm{F}_{3,80}=0.089 ; \mathrm{P}=0.966\right)$. Hal serupa juga tampak pada hasil analisis interaksi antara dosis dan waktu. Hasil analisis menunjukkan bahwa tidak terdapat interaksi 
yang nyata antara dosis dan waktu pemaparan terhadap diameter C. gloeosporioides $\left(\mathrm{F}_{12,80}=1.757 ; \mathrm{P}=0.77\right)$.

Perlakuan EtF secara in Vitro terhadap C. gloeosporioides pada Buah Stroberi

Hasil perlakuan EtF terhadap buah stroberi menunjukkan pertumbuhan cendawan tidak berbeda dengan kontrol. Hal ini ditandai dengan munculnya gejala penyakit pada buah stroberi untuk semua dosis dan waktu pemaparan (Gambar 1).

Kerusakan Kelopak dan Buah Stroberi. Perlakuan EtF dengan dosis $140 \mathrm{~g} \mathrm{~m}^{-3}$ menunjukkan tingkat kerusakan kelopak stroberi tidak berbeda dengan kontrol. Namun demikian, perlakuan pada dosis 190$290 \mathrm{~g} \mathrm{~m}^{-3}$ berbeda nyata. Tingkat kerusakan pada kelopak berbeda-beda berdasarkan dosis EtF yang diberikan. Dosis $190 \mathrm{~g} \mathrm{~m}^{-3}$ termasuk kategori 1 (tidak ada kerusakan), dosis $240 \mathrm{~g} \mathrm{~m}^{-3}$ termasuk kategori 2 (sedikit kerusakan) dan kategori 3 (moderat kerusakan) pada dosis $290 \mathrm{~g} \mathrm{~m}^{-3}$ (Tabel 2). Pengaruh perlakuan EtF terhadap perubahan warna buah stroberi pada berbagai taraf dosis tidak berbeda nyata dengan kontrol (Gambar 2, Tabel 3).

Hasil analisis menunjukkan bahwa dosis berpengaruh secara nyata terhadap kerusakan kaliks $\left(\mathrm{F}_{4,80}=113.919 ; \mathrm{P}=0.000\right)$ dan waktu berpengaruh secara nyata terhadap kerusakan kaliks $\left(\mathrm{F}_{3,80}=3.541 ; \mathrm{P}=0.020\right)$. Namun hasil analisis interaksi antara dosis dan waktu menunjukkan bahwa tidak terdapat interaksi yang nyata antara dosis dan waktu pemaparan terhadap kerusakan kaliks $\left(\mathrm{F}_{12,80}=1.919\right.$; $\mathrm{P}=0.050$ ).

Hasil analisis menunjukkan bahwa dosis tidak berpengaruh secara nyata terhadap kerusakan buah $\left(\mathrm{F}_{4,80}=0.250 ; \mathrm{P}=0.909\right)$ dan waktu tidak berpengaruh secara nyata terhadap kerusakan buah $\quad\left(\mathrm{F}_{3,80}=0.250 ; \quad \mathrm{P}=0.861\right)$. Hal serupa juga tampak pada hasil analisis interaksi antara dosis dan waktu. Hasil analisis menunjukkan bahwa tidak terdapat interaksi yang nyata antara dosis dan waktu pemaparan terhadap kerusakan buah $\left(\mathrm{F}_{12,80}=0.667\right.$; $\mathrm{P}=0.776$ ).
Cendawan Lain yang Muncul pada Buah Stroberi. Terdapat cendawan lain yang muncul pada buah stroberi yang diberi perlakuan maupun tanpa perlakuan EtF. Spesies cendawan lain yang muncul pada buah stroberi yaitu Colletotrichum sp. dan Botrytis sp.

Munculnya cendawan $C$. gloeosporioides tanpa diinokulasikan dibuktikan di bawah mikroskop cahaya ditandai dengan adanya struktur konidium berbentuk oval, hialin, tidak bersepta, ukurannya 13.4-24 x 4.0$5.9 \mu \mathrm{m}$. Hifanya bercabang, bersepta, dan hialin. Bentuk apresorium obovate sampai clavate, warna cokelat, ukuran 6.7-19.8 x 3.8$11.9 \mu \mathrm{m}$.

Cendawan Botrytis sp. yang muncul di permukaan buah memiliki konidium berbentuk oval atau batang yang tidak bersepta. Konidium berwarna cokelat gelap, bercabang, pada ujungnya terdapat kumpulan kondium.

\section{PEMBAHASAN}

Walaupun pengaruh EtF tidak mampu menekan cendawan hingga $100 \%$, namun dapat mempengaruhi perkembangan koloni cendawan terutama pada dosis 190, 240, dan $290 \mathrm{~g} \mathrm{~m}^{-3}$ dengan rata-rata masing-masing diameter koloni sebesar 34.76, 28.68, dan $40.37 \mathrm{~mm}$. Menurut Kumar (2007) pada dosis EtF 200-400 ppm dapat menghambat cendawan Aspergillus parasiticus pada medium PDA secara in vitro $21-90.2 \%$ serta cendawan tidak tumbuh pada dosis $600 \mathrm{ppm}$. Laporan penelitian sebelumnya menyatakan bahwa senyawa EtF belum banyak digunakan untuk cendawan dibandingkan dengan senyawa ester lainnya. Sebagaimana yang dilaporkan oleh Phil dan Lynn (2011) etil asetat adalah salah satu senyawa ester yang diperoleh dari tanaman Juniperus virginiana yang pada konsentrasi $2.5 \mathrm{mg} \mathrm{mL}^{-1}$ dapat menekan cendawan Gloeophyllum trabeum sebesar 77\% dan Trametes versicolor perusak tanaman kayu secara in vitro sebesar $48 \%$.

Norman (1969) melaporkan bahwa efek senyawa ester yang dihasilkan oleh cendawan 
Tabel 1 Pengaruh perlakuan etil format terhadap pertumbuhan koloni Colletotrichum gloeosporioides secara in vitro pada 7 hari setelah perlakuan

\begin{tabular}{cccccc}
\hline $\begin{array}{c}\text { Waktu } \\
\text { (jam) }\end{array}$ & 0 & 140 & 190 & 240 & 290 \\
\cline { 2 - 6 } & $54.75 \pm 0.95$ & $47.75 \pm 2.06$ & $24.00 \pm 12.35$ & $38.00 \pm 4.89$ & $40.00 \pm 11.88$ \\
1 & $53.75 \pm 2.87$ & $42.75 \pm 7.97$ & $39.00 \pm 6.21$ & $29.50 \pm 16.05$ & $39.00 \pm 12.49$ \\
2 & $54.50 \pm 1.73$ & $49.50 \pm 2.64$ & $29.25 \pm 4.42$ & $24.50 \pm 11.15$ & $42.25 \pm 20.93$ \\
3 & $54.00 \pm 0.81$ & $44.00 \pm 2.16$ & $46.75 \pm 11.20$ & $22.75 \pm 11.87$ & $40.25 \pm 10.14$ \\
4
\end{tabular}
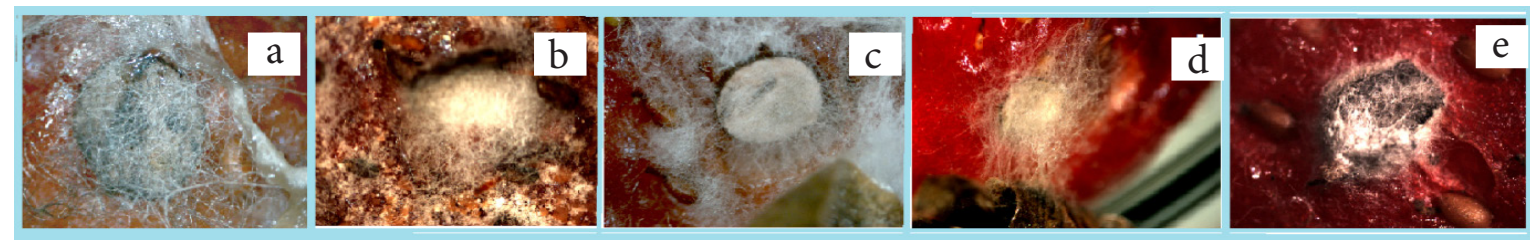

Gambar 1 Pertumbuhan Colletotrichum gloeosporioides pada buah stroberi 7 hari setelah perlakuan: dosis EtF a, $140 \mathrm{~g} \mathrm{~m}^{-3}$; b, $190 \mathrm{~g} \mathrm{~m}^{-3}$; c, $240 \mathrm{~g} \mathrm{~m}^{-3}$; d, $290 \mathrm{~g} \mathrm{~m}^{-3}$; e, kontrol.

Tabel 2 Pengaruh perlakuan EtF terhadap kerusakan kaliks

\begin{tabular}{lccccc}
\hline $\begin{array}{l}\text { Waktu } \\
\text { (jam) }\end{array}$ & 0 & 140 & 190 & 240 & 290 \\
\cline { 2 - 6 } & $1.00 \pm 0.00$ & $1.00 \pm 0.00$ & $1.50 \pm 0.57$ & $2.50 \pm 0.57$ & $3.75 \pm 0.50$ \\
2 & $1.00 \pm 0.00$ & $1.50 \pm 0.57$ & $1.75 \pm 0.50$ & $2.00 \pm 0.00$ & $3.50 \pm 0.57$ \\
3 & $1.00 \pm 0.00$ & $1.25 \pm 0.50$ & $2.00 \pm 0.00$ & $2.75 \pm 0.50$ & $3.25 \pm 0.50$ \\
4 & $1.00 \pm 0.00$ & $1.75 \pm 0.50$ & $1.75 \pm 0.50$ & $3.00 \pm 0.00$ & $4.00 \pm 0.00$ \\
\hline
\end{tabular}
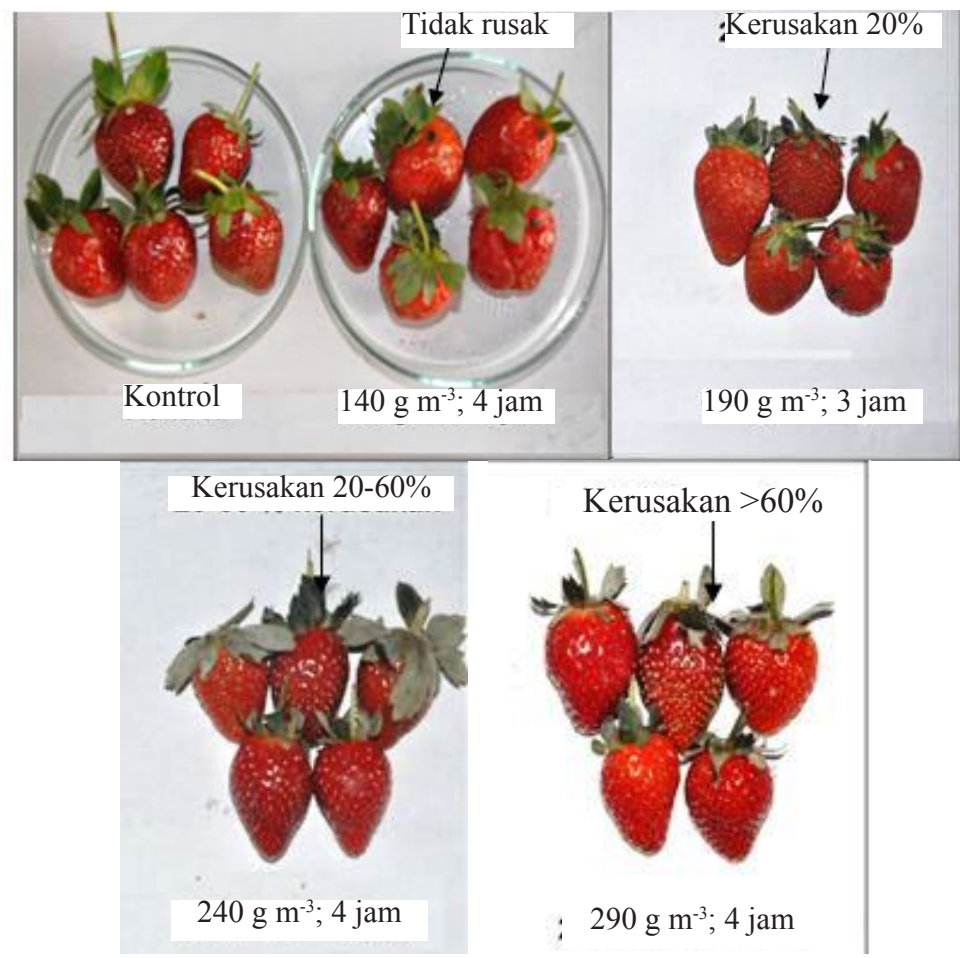

Gambar 2. Perbandingan kerusakan kelopak dan buah stroberi terhadap perlakuan etil format 7 hari setelah perlakuan. 
Tabel 3 Pengaruh perlakuan etil format terhadap kerusakan buah

\begin{tabular}{lccccc}
\hline Waktu & \multicolumn{5}{c}{ Dosis $\left(\mathrm{g} \mathrm{m}^{-3}\right)$} \\
\cline { 2 - 6 } (jam) & 0 & 140 & 190 & 240 & 290 \\
\hline 1 & $1.25 \pm 0.50$ & $1.00 \pm 0.00$ & $1.25 \pm 0.50$ & $1.25 \pm 0.50$ & $1.00 \pm 0.00$ \\
2 & $1.25 \pm 0.50$ & $1.25 \pm 0.50$ & $1.25 \pm 0.50$ & $1.25 \pm 0.50$ & $1.25 \pm 0.50$ \\
3 & $1.25 \pm 0.50$ & $1.25 \pm 0.50$ & $1.25 \pm 0.50$ & $1.25 \pm 0.50$ & $1.25 \pm 0.50$ \\
4 & $1.00 \pm 0.00$ & $1.25 \pm 0.50$ & $1.25 \pm 0.50$ & $1.00 \pm 0.00$ & $1.75 \pm 0.50$ \\
\hline
\end{tabular}

Dypodascus aggregatus, di antaranya ialah EtF mampu mengurangi pertumbuhan dan menurunkan produksihifacendawan Pestalotia rhododendri secara in vitro. Hal ini juga ditunjukkan oleh Utama et al. (2002) bahwa ada pengaruh pada pertumbuhan cendawan Rhizoctonia stolonifer dan Colletotrichum musae setelah diperlakukan dengan EtF secara in vitro. Menurut Adam (1996), senyawa ester dari etil oleat hidroperoksida 1a dan alkohol $1 \mathrm{~b}$ dapat menghambat pembentukan 8-oxoGua untuk oksidatif DNA hingga $85 \%$.

Perlakuan EtF pada buah stoberi hanya dapat mengurangi pertumbuhan koloni cendawan dan tidak menghambat pertumbuhan. Munculnya tanda C. gloeosporioides pada buah stroberi terlihat dengan adanya miselium di permukaan buah yang berwarna putih abu-abu. Gejala yang disebabkan $C$. gloeosporioides disebut busuk cokelat pada permukaan buah jika gejala berat. Intensitas kerusakan yang disebabkan oleh penyakit ini dapat mencapai 57\% sehingga penyakit ini memiliki kontribusi kehilangan hasil yang tinggi. Menurut Agrios (2005) gejala pada buah stroberi ditandai dengan layu cokelat yang ditutupi massa konidium dari C. gloeosporioides dan bentuknya menjadi berubah seperti cekung disebut busuk cekung, bercak semakin luas dan menutupi seluruh permukaan buah menjadi hitam.

Perlakuan dosis EtF menyebabkan kerusakan pada buah stroberi. Simpson et al. (2007) melaporkan perlakuan EtF pada dosis $1.6 \%$ dan $2.4 \%$ EF selama 60 menit terdapat kerusakan kaliks (warna, kekokohan) pada buah stroberi pada tingkat kerusakan 3 (kerusakan moderat) dan 4 (kerusakan berat). Aharoni (1980) menyatakan bahwa perlakuan EtF dengan dosis $0.5 \%$ atau $1.0 \%$ di bawah udara vakum tidak menyebabkan kerusakan kaliks, kehilangan kualitas organoleptik atau aromanya.

Demikian pula, Ryan et al. (2004) melaporkan bahwa perlakuan EtF pada dosis $0.6 \%$ EtF selama 6 jam tidak mempengaruhi kualitas warna kulit buah pisang setelah dua minggu disimpan pada suhu $13-14{ }^{\circ} \mathrm{C}$.

Dari hasil pengamatan pertumbuhan cendawan lain menunjukkan adanya hambatan walaupun tidak berbeda dengan kontrol. Hal ini diduga disebabkan oleh faktor fumigasi EtF yang memacu peningkatan senyawa yang ada di dalam buah stroberi. Menurut Sympson et. al (2004) terdapat peningkatan kandungan senyawa etanol mencapai 12 kali, begitu juga kandungan etil asetat 8 kali, dan senyawa etil format 3 kali setelah perlakuan dosis $1.6 \%$ EtF selama 60 menit pada buah stroberi. Berdasarkan hasil pengujian dapat disimpulkan bahwa perlakuan EtF dapat mengurangi pertumbuhan C. gloeosporioides secara in vitro. Walaupun demikian, perlakuan EtF pada dosis tertentu dapat menyebabkan kerusakan kaliks atau buah stroberi.

\section{DAFTAR PUSTAKA}

Adam W, Andler S, Chantu R, SahaMöller, Schönberger A. 1996. Inhibitory effect of ethyl oleate hydroperoxide and alcohol in photosensitized oxidative DNA damage. J Photochem Photobiol B. 34(1):51-8. doi:10.1016/1011-1344(95)07235-7.

Agrios GN. 2005. Plant Pathology. Ed ke-5. New York (US): Academic Press.

Aharoni Y, Stewart JK, Guadagni DG, Mon TR, 1980. Thrips mortality and strawberry quality after vacuum fumigation with 
acetaldehyde or ethyl formate. J Am Soc Hort Sci. 105(6):926-929. doi 10.1016/j. postharvbio.2004.05.015.

Ellis MA, Erincik O. 2008. Anthracnose of strawberry. fact sheet. The Ohio State University. http://ohioline.osu.edu/ hyg-fact/3000/pdf/HYG_3209_08.pdf. [diunduh tanggal 12 April 2013].

Damcevski KA, Dojchinov G, Woodman J D, Haritos V S. 2010. Efficacy of vaporised ethyl formate/carbon dioxide formulation against stored-grain insects: effect of fumigant concentration, exposure time and two grain temperatures. Pest Manag Sci. 66(4):432-438.

Direktorat Perlindungan Hortikultura. 2011. www.ditlin.hortikultura.deptan.go.id [diakses 7 Juli 2012].

European Medicines Agency [EMA]. 2009. Impurities: Guideline for Residual Solvents. Science Medicine Health. London. United Kingdom. http://www. ema.europa.eu/docs/en_GB/document library/Scientific guideline/2009/09/ WC500002674.pdf [diakses 8 Agu 2012].

Gorris LGM, Smid EJ. 1995. Crop protection using natural antifungal compounds. Pestic Outlook. 6(5):20-24.

Kumar P, Chauhan TR, Gera R Kumar N. 2007. Significance of ethyl formate in controlling the fungal growth in stored grains. http://mbao.org/2007/ Proceedings/100KumarPSummary.pdf. [diakses 7 Juli 2012].
Norman J. 1969. Production of volatile organic compounds by the yeast fungus dipodascus aggregates. Arch Microbiol. 68(2):133-149.

Fields PG, White NDG. 2002. Alternatives to methyl bromide treatments for storedproductand quarantine insects. Annu Riv Entomol. 47:331-359. doi: 10.1146/ annurev.ento.47.091201.145217.

Phil SM, Lynn P. 2011. Antifungal activity of organic extracts from Juniperus virginiana heartwood against wood decay fungi. http://www.freepatentsonline.com/article/ Forest-Products-Journal/279613793.html. [diaskes 8 April 2013].

Ryan R F, Krishna H, Bishop S R, Brash D, Mitcham E. 2004. Development of vapormate for postharvest quality. ISHS Acta Horticulturae 687. http://www. actahort.org/books/687/687_63.htm. [diakses 23 Okt 2012].

Simpson T, Bikoba V, Tipping C, Micham E. J. 2007. Ethyl formate as a postharvest fumigant for selected pests of table grapes. J Econ Entomol. 100(4):1084-1090. doi: 10.1603/0022-0493(2007)100[1084:EFA APF]2.0.CO;2.

Utama I M, Wills R B, Ben-Yehoshua S, Kuek C. 2002. In vitro efficacy of plant volatiles for inhibiting the growth of fruit and vegetable decay microorganisms. J Agric Food Chem. 50(22):6371-7. 